\title{
Passion and Role Opportunity Search: Interfering Effects of Conflicts and Overloads
}

\author{
Sara Thorgren \\ (corresponding author) \\ Luleå University of Technology; Entrepreneurship \& Innovation \\ 97187 Luleå, Sweden \\ Tel.: +46920 492342 E-mail: sara.thorgren@ltu.se
}

\begin{abstract}
Joakim Wincent
Luleå University of Technology; Entrepreneurship \& Innovation

97187 Luleå, Sweden
\end{abstract}

Tel.: +46920 492161 E-mail: joakim.wincent@ltu.se

Acknowledgment

We gratefully thank the editor Sharon Glazer and the three anonymous reviewers for their excellent comments and feedback. We would also like to acknowledge the financial support provided by the Swedish Research Council, the Swedish Council for Working Life and Social Research, and Handelsbanken's Research Foundations. 


\title{
Passion and Role Opportunity Search: Interfering Effects of Conflicts and Overloads
}

\author{
ABSTRACT \\ Individuals' search for various opportunities within the context of their job (role opportunity \\ search) is an important yet demanding characteristic of today's work environments. This \\ study tests the effects of harmonious passion and obsessive passion on role tensions (i.e., role \\ conflict and role overload), which is posited to influence the search for new role \\ opportunities. The results of structural equation modeling $(\mathrm{GFI}=.92 ; \mathrm{IFI}=.90$; RMSEA $=$ \\ .07) on survey data from Swedish owner-managers $(n=704)$ supported that harmonious \\ passion has a negative relationship with role conflict $(\beta=-.14)$, which in turn has a negative \\ relationship with role opportunity search $(\beta=-.21)$. This results in a positive, indirect \\ relationship between harmonious passion and role opportunity search. In contrast, the \\ positive relationship between obsessive passion and role conflict $(\beta=.44)$, results in a \\ negative indirect relationship with role opportunity search. The relationships applied for \\ passion were also applied to role overload (harmonious passion: $\beta=-.26$; obsessive passion: \\ $\beta=.41, p<.001$ ), but no significant influence was found from role overload to role \\ opportunity search. This study provides insight into the importance of considering role \\ tension in passion models, especially when explaining role opportunity search. As \\ demonstrated, whether role opportunity search will be facilitated or hindered by passion \\ originates based on whether the passion is harmonious or obsessive.
}

Keywords: Harmonious passion; obsessive passion; role tension; role conflict; role overload; role opportunity; search 


\section{INTRODUCTION}

Work life is changing rapidly in many ways. For an increasing number of individuals, it has become progressively more essential to be alert to role changes and look for new opportunities in one’s own work role (Cooper, Graham, \& Dyke, 1993; Eby, Butts, \& Lockwood, 2003; Judge, Higgins, Thoresen, \& Barrick, 1999). The concept of "role opportunity search,” defined as individuals’ behavioral tendency to take actions to find new contexts to engage with their role attributes, has become an important aspect of organizational science (Blau, 1988; Judge, Cable, Boudreau, \& Bretz, 1995; Turban \& Dougherty, 1994). More research attention has focused on people’s search for new opportunities and their propensity to act on them, because opportunities trigger some individuals to see potential that others have not yet seen or are unwilling to act upon. In recognizing opportunities and taking action, these individuals can become critical drivers in the economy by creating growth at both the micro and macro levels. It thus becomes interesting to identify the factors that influence individuals to search for new opportunities.

It has been suggested that passion represents an important psychological factor related to work behavior and that it is a resource from which individuals might receive energy (Ho, Wong, \& Lee, 2011). Passion might have a direct relationship with the way people approach opportunities in general (Cardon, Wincent, Singh, \& Drnovsek, 2009; Murnieks, Mosakowski, \& Cardon, in press), and as a resource passion might trigger search behavior. Still, we expect that when we specifically consider search behavior related to pursuing new opportunities in one’s own work role, other mechanisms might be involved. Of particular interest to the present study’s inquiry, and as Jaros, Jermier, Koehler, and Sincich (1993) critically questioned, how do constructs such as passion influence role opportunity search?

Several researchers have noticed that highly motivated individuals often stay in their current work settings even when, objectively, it would be better if they broadened their search 
behavior and looked for new opportunities (Lee, Ashford, Walsh, \& Mowday, 1992; Mathieu \& Zajac, 1990; Meyer, Stanley, Herscovitch, \& Topolnytsky, 2002). Evidently, more specific theorizing and testing is needed to gain a comprehensive understanding of the relationship between one's passion toward work and one's search for new role opportunities. In other words, we need to examine more thoroughly why we can expect passion to relate both positively and negatively with role opportunity search.

In the present study, we highlight how role tension (Katz \& Kahn, 1978; Rizzo, House, \& Lirtzman, 1970) might interfere with the work passion-work role opportunity search relationship. Role tension results from unclear or conflicting expectations for a specific role (Kahn, Wolfe, Quinn, Snoek, \& Rosenthal, 1964), and role tension predicts work-related behaviors and attitudes (Eatough, Chang, Miloslavic, \& Johnson, 2011; Fried, Shirom, Gilboa, \& Cooper, 2008; Gilboa, Shirom, Fried, \& Cooper, 2008; Örtqvist \& Wincent, 2006; Tubré \& Collins, 2000; Wincent \& Örtqvist, 2009). Given that (1) passion might relate to role opportunity and (2) the link between role tension and subsequent behaviors and attitudes, it is of great interest to link passion to role tension. Thus, the present research aims to test if role tensions, in the form of role conflict and role overload, might interfere with the passion-opportunity search relationship. Role conflict is the extent to which the work role is characterized by conflicting expectations, whereas role overload is defined as the extent to which these expectations are difficult to meet (Katz \& Kahn, 1978; Rizzo et al., 1970).

The present study's conceptualization of passion is based on the Dualistic Model of Passion proposed by Vallerand, Blanchard, Mageau, Koestner, Ratelle, Leonard, Gagne, and Marsolais (2003), which has received high recognition in subsequent passion research (e.g., Mageau, Vallerand, Rousseau, Ratelle, \& Provencher, 2005; Stoeber, Harvey, Ward, \& Childs, 2011; Wang \& Chu, 2007). Vallerand et al. proposed that two distinct types of 
passion might develop: harmonious passion and obsessive passion. Both are defined as a strong inclination toward an activity that is self-defining and something that one loves and finds important. Furthermore, the activity is something on which one spends significant time and energy. The two types of passion differ, however, based on how they are internalized. For harmonious passion, the activity is part of an integrated self-structure (Hodgins \& Knee, 2002), and thus it is important to the individual's identity but does not occupy an overpowering space. The individual controls his or her own engagement in the activity and freely desires to engage in it. In contrast, obsessive passion is not part of an integrated selfstructure in which the individual functions autonomously. Instead, the individual is driven by an urge, which he or she cannot control him- or herself, to engage in the activity because of ego-invested self-structures. In other words, the activity is associated with a constructed self and occupies a disproportionately large space within one’s identity.

Subsequent to Vallerand et al.’s (2003) seminal study, the growing body of research that draws upon the Dualistic Model of Passion supports that these two types of passion are plausible and that their outcomes differ (e.g., Bonneville-Roussy, Lavigne, \& Vallerand, 2011; Donahue, Rip, \& Vallerand, 2009). For example, it has been demonstrated that harmonious passion relates to adaptive outcomes, whereas obsessive passion relates to maladaptive outcomes. More specifically, harmonious passion positively relates to lifesatisfaction (Bonneville-Roussy, et al., 2011); work satisfaction (Carbonneau, Vallerand, Fernet, \& Guay, 2008); and positive affect (Gustafsson, Hassmen, \& Hassmen, 2011) and negatively related to burnout (Carbonneau et al., 2008) and negative affect (Gustafsson et al., 2011). Obsessive passion, however, positively relates to intrapersonal conflict (Stenseng, 2008) and activity addiction (Stenseng, Rise, \& Kraft, 2011), and negatively relates to mental health (Forest, Mageau, Sarrazin, \& Morin, 2011) and cognitive attention (Ho et al., 2011). Because passion is a two-dimensional conceptualization and each results in distinct 
outcomes, the Dualistic Model of Passion is highly relevant to theorizing when and why passion might result in an increased search for role opportunities and under what conditions it might not. The hypothesized model (illustrated in Figure 1) proposes that the two types of passion shape the experience of role tensions in distinct ways and ultimately effect behavior in relation to opportunity search.

Regarding harmonious passion and role tensions, we expect that an ultimately positive relationship exists with role opportunity search because harmoniously passionate people might expend more effort to achieve self-realization and fulfillment based on authenticity. This, in turn facilitates the search for new role opportunities. Such a proposal draws upon the conceptualization in the Dualistic Model of Passion that harmonious passion is part of an autonomous, or what can also be called an integrated, self-structure (Vallerand et al., 2003; Verner-Filion, Lafreniere, \& Vallerand, 2012). This autonomy is associated with being open and responsive to reality and new experiences (Hodgins \& Knee, 2002). People with an autonomous self-structure generally orient themselves toward learning and growth (Knee \& Zuckerman, 1996) and adopt a less defensive approach to stressful events (Knee \& Zuckerman, 1998). How they approach reality becomes guided by interest and choice (Knee, Neighbors, \& Vietor, 2001). This makes it likely that the link between harmonious passion and the experience of role tensions is negative. Thanks to autonomous characteristics, harmoniously passionate people have an approach to reality in which multiple role expectations might not be experienced overwhelmingly extensive or incompatible. Instead, experiences from expectations might be considered a source of information and something from which they can learn (Hodgins, Koestner, \& Duncan, 1996). This negative relationship between harmonious passion and role tensions might facilitate, in turn, the search for new role opportunities. From prior research (e.g., Örtqvist \& Wincent, 2006), we know that those who experience role tension spend extensive time thinking about and trying to manage 
tensions, leaving little time and cognitive attention available to search for new role opportunities. Ultimately, we expect an indirect positive relationship between harmonious passion and role opportunity search.

Obsessive passion is expected, however, to have the opposite relationship to role tension and ultimately to opportunity search. The ego-invested self-structures on which obsessive passion builds makes it likely that a positive relationship exists toward the experience of role tensions. Such self-structures mean that the individual constructs a self that he or she desires to protect. The person's focus turns to relating and comparing surrounding experiences and events to the self when regulating one’s own behaviors (Hodgins \& Knee, 2002). Instead of facing reality openly, obsessively passionate people aim to protect and defend their own constructed self by ensuring that how they interact with others and interpret feedback is self-confirmatory. Pressure builds on how one 'should' behave (Hodgins et al., 1996), which results in defensive coping strategies and constraints on the authenticity of one’s behavior (Knee \& Zuckerman, 1998). In other words, ego-invested self-structures direct people to regulate their responses to pressure and contingencies (Knee et al., 2001). Such self-protection is likely to be problematic for how role expectations are perceived, both in terms of their extent and compatibility. It might be difficult to see how one responds to expectations when one's behavior is constrained by efforts to self-justify and the wish to escape awareness of the present moment. From a wider perspective, therefore, we expect a negative, indirect relationship between obsessive passion and role opportunity search, such that high obsessive passion will relate to more role tensions, which limits the time and energy available to search for new role opportunities. We therefore hypothesize:

Hypothesis 1. Harmonious passion and obsessive passion have distinct relationships with opportunity search through role conflict: (1a) harmonious passion is negatively related to role 
conflict and (1b) obsessive passion is positively related to role conflict, which (1c) in turn is negatively related to opportunity search.

Hypothesis 2. Harmonious passion and obsessive passion have distinct relationships with opportunity search through role overload: (2a) harmonious passion is negatively related to role overload and (2b) obsessive passion is positively related to role overload, which (2c) in turn is negatively related to opportunity search.

\section{CONTEXTUAL BACKGROUND}

The present study was conducted in Sweden and surveyed a sample of Swedish business owner-managers. As such, reviewing Hofstede’s cultural dimensions (Hofstede, Hofstede, \& Minkov, 2010)—power distance, individualism, masculinity, uncertainty avoidance, and long-term orientation-provides insight into the cultural values related to organizations and management in Sweden. Sweden has a low score on power distance (PDI = 31), meaning that independence and equal rights are important. Coaching and empowering are also highly valued, which is consistent with decentralized power. Swedish managers expect that employees are knowledgeable and should be consulted and participate in decisions. Sweden is also considered an individualistic society (IDV = 71), meaning people define themselves as "I” rather than "we.” Within organizations, people are expected to take care of themselves, and contracts are based on mutual advantages for the employee and employer. On the masculinity dimension, Sweden scores low (MAS = 5), indicating a feminine society in which one's quality of life and liking what one does are more important than being "the best." For organizational behavior, this means decisions result from employee involvement, and compromise and negotiation are common ways to resolve conflicts.

Sweden also scores low on the uncertainty avoidance dimension (UAI = 29). In general, people do not feel threatened by ambiguous or unknown situations. Consequently, rules tend 
to be moderate, schedules are flexible, and innovation is viewed positively. On the fifth dimension, long-term orientation, Sweden scores low (LTO $=20)$; thus, society has a shortterm orientation. Social pressure to "keep up with the Joneses” and produce quick results predominate. In sum, Sweden’s scores on Hofstede’s (2010) five cultural dimensions suggest that the country's cultural values encourage people to shape and search for new role opportunities. Notably, however, Swedes’ role opportunity search might mean shaping a role into "what I like and what benefits me" rather than "becoming the best and benefiting the group.” Worth noticing is that while this gives a background to the study context, the nature of Sweden's culture was not taken into account when the results were analyzed.

\section{METHODS}

\section{Sample and Procedure}

Hypotheses were tested using a sample of Swedish owner-managers (cf. Baum, Locke, \& Smith, 2001). To increase similarities among the owner-managers’ work roles, we collected data from managers that all started their company in the same time period. We also wanted managers to have been engaged in their companies for at least two years to ensure that role interactions had occurred with numerous persons in the role set. We therefore decided that an adequate sample would include participants who all started a company in 2008. Using the exhaustive Swedish database Affärsdata, we mapped the entire population of limited companies registered in 2008, which resulted to 8,796 companies. From this total, we drew a random sample of 3,000 companies. By the end of 2010, we mailed a hardcopy questionnaire to the owner/founder who was actively managing each company (i.e., one company equaled one questionnaire). The cover letter explained that we were interested in their thoughts and experiences related to their work role and that they were ensured confidentiality. We received 704 completed questionnaires, reflecting a response rate of 
23.5\%. This aligns well with other studies using similar study designs (e.g., Hmieleski \& Corbett, 2008). Using unpaired $t$-tests, we considered possible differences between the firms that respondents and non-respondents managed and found non-significant results: venture turnover $(t=.81, p=.42)$, venture performance $(t=1.18, p=.24)$, and number of employees $(t=.70 ; p=.49)$. Among the 704 respondents, 561 were male and 143 female; their age ranged between 22 and 76 years, with an average age of 46.5 years (s.d. $=10.7)$. This is comparable to national statistics, which show that $22.7 \%$ of all Swedish small businesses (0-49 employees) are managed by women, and 54.9\% of all small businesses are managed by people aged 38 to 57 years old (Tillväxtverket, 2011).

\section{Measures}

Unless otherwise stated, we used a 5-point Likert scale for our measures, anchored by 1 = strongly disagree to 5 = strongly agree.

\section{Passion variables}

We used the Passion Scale to assess the two types of passion Vallerand et al. (2003) suggested. Whereas the original Passion Scale included seven items for each type of passion, we used a shortened version (similar to other subsequent studies) with five items for harmonious passion and five items for obsessive passion (Mageau et al., 2005; Przybylski, Weinstein, Ryan, \& Rigby, 2009; Ratelle, Vallerand, Mageau, Rousseau, \& Provencher, 2004). Respondents were asked to reflect on how they experienced entrepreneurship as new business founders by indicating the extent to which they agreed with each item. A sample item for harmonious passion was: "Running a business is in harmony with the other activities in my life.” This scale had a coefficient alpha of .81 (mean $=3.72$, s.d. $=0.69$ ). For obsessive passion a sample item was: "I have a tough time controlling my need to engage in running a business.” This scale had a coefficient alpha of $.80($ mean $=2.77$, s.d. $=0.90)$. 


\section{Role tension variables}

We used three items from the Rizzo et al. (1970) questionnaire to assess to what extent the respondents experienced role conflict. We made some minor word modifications to make the items relevant to the context of entrepreneurs. A sample item for role conflict was: "I do things that are apt to be accepted by one stakeholder/actor and not accepted by others (e.g., customers, shareholders, and employees).” The coefficient alpha for this scale was .71 (mean $=2.36$, s.d. $=0.90)$. To capture the extent respondents experienced role overload as an entrepreneur, we used four items from the scale developed by Beehr, Walsh, and Taber (1976). A sample item for role overload was: “I'm rushed in doing my job.” This scale had a coefficient alpha of $.73($ mean $=3.06$, s.d. $=1.01)$.

Outcome variable. To contextualize “role opportunity search,” the present study’s ultimate dependent variable, we consulted the literature on role opportunities for ownermanagers (e.g., Short, Ketchen, Shook, \& Ireland, 2010). This variable was based on respondents' self-assessments of the extent to which they were currently expending effort to (1) start another new company and (2) buy or change an existing company.

\section{Confirmatory Factor Analysis}

We conducted confirmatory factor (CFA) analysis using AMOS to ensure convergent and discriminant validity of our measures (Bollen, 1989). The 5-factor measurement model—measuring entrepreneurs' harmonious and obsessive passion, role conflict, role overload, and opportunity search—provided a good fit with the data $\left(\chi^{2}[122, n=\right.$ 704 $]=$ 531.84; RMSEA $=.06 ;$ GFI $=.92$, IFI $=.90)$. All variable items loaded significantly on the latent constructs they were aimed to measure, and critical assessments with exploratory factor analysis ensured no cross-loadings and clean factor structures. The standardized factor loadings ranged from .53 to .86. Indicating the distinctiveness among the five latent factors, correlations between them ranged from - .18 to .43 . To assess discriminant 
validity, we used the CFA results to compare the average variance extracted (AVE) with the shared variance between constructs (Fornell \& Larcker, 1981). In each case, AVE was greater than its variance with any of the other constructs, which indicates discriminant validity.

\section{RESULTS}

As presented in Figure 1 and Table 1, our model assumes no direct effects exist from the two types of passion to role opportunity search. To test this assumption, we first used AMOS to analyze the individual coefficients in three competing models: (1) a saturated model, (2) a direct effects model, and (3) our hypothesized model (see Table 1). Noticing that neither the direct relationship between harmonious passion and role opportunity search nor the direct relationship between obsessive passion and role opportunity search was significant, we next present the results from our hypothesized model. All coefficients linking harmonious and obsessive passion to the two indicators of role tension were in the predicted direction and statistically significant. Specifically, a negative relationship exists between harmonious passion and role conflict $(\beta=-.14, p<.01)$ and a positive relationship exists between obsessive passion and role conflict $(\beta=.44, p<.001)$. This provides support for Hypotheses 1a and 1b. As predicted, we found a negative relationship between role conflict and opportunity search $(\beta=-.21, p<.01)$. Hypothesis 1 c was thus supported. We also consulted the Sobel (1982) test to examine whether the indirect effect of the two passion variables on opportunity search through role conflict was significant. This provided further evidence for both the indirect path from harmonious passion (Sobel statistic $=2.02, p<.05$ ) and from obsessive passion (Sobel statistic $=2.58, p<.001$ ).

Regarding passion and role overload, results support a similar pattern: harmonious passion has a negative relationship with role overload $(\beta=-.26, p<.001)$, whereas obsessive passion has positive relationship with role overload $(\beta=.41, p<.001)$. Our results did not, 
however, support Hypothesis 2c, which predicted a negative relationship between role overload and opportunity search $(\beta=.04$, ns). Thus, the results do not support indirect relationships between the two types of passion and opportunity search through role overload.

--- INSERT FIGURE 1 ABOUT HERE---

---INSERT TABLE 1 ABOUT HERE---

\section{DISCUSSION}

This study tested if role tensions (role conflict and role overload) influence the relationship between individuals' passion toward work and their search for new work role opportunities. By applying the Dualistic Model of Passion (the notion harmonious and obsessive passion), we found that one cannot say that passion toward work solely facilitates or mitigates the search for new role opportunities. Instead, a more fine-grained analysis is needed to look at the two types of passion separately. In doing so, our findings show that harmonious passion has a positive, indirect relationship with role opportunity search, whereas obsessive passion has a negative, indirect relationship. These indirect relationships are identified by acknowledging that role tensions may interfere with the relationship between passion and opportunity search. More specifically, we hypothesized that harmonious passion would negatively relate with both role conflict and role overload and that obsessive passion would positively relate with these variables. The next hypothesized associations in our model, from role conflict and role overload to opportunity search, were supported between role conflict and opportunity search, but not between role overload and opportunity search. Specifically, the results support different relationships between harmonious and obsessive passion and opportunity search, which occurs through role conflicts. This means that role 
conflict constitutes an important mediation function for understanding workers' search for new role opportunities.

The present study makes several theoretical contributions. First, it recognizes that the Dualistic Model of Passion (Vallerand et al., 2003) is useful for gaining a more comprehensive understanding of passion consequences in a work context. It provides an understanding regarding why passion in some cases might be considered a resource that provides energy to search for new opportunities, whereas in other cases, passion seems to hinder such efforts by influencing the individual to maintain the status quo. As such, this study encourages future research to apply the Dualistic Model of Passion to research questions that investigate the consequences of passion in organizational contexts. By considering both harmonious and obsessive passion and examining their effects, we can identify differences that refer to how passion is internalized into one's self-concept (controlled or autonomous internalization). Second, our study contributes to the dualistic model by integrating passion with role tension. Although previous research applying the Dualistic Model of Passion has touched on similar topics by testing and finding that the two types of passion have different effects on work-family interference (Caudroit, Boiche, Stephan, Le Scanff, \& Trouilloud, 2011), perceived stress (Gustafsson et al., 2011), and the quality of interpersonal relationships (Philippe, Vallerand, Houlfort, Lavigne, \& Donahue, 2010), the present study is the first to integrate the two types of passion with role theory in general and role tensions specifically. The results indicate that future understandings of passion can gain much from integrating the Dualistic Model of Passion with role theory. Third, it also contributes to role tension research. To the best of our knowledge, this is the first study to highlight passion as an antecedent to role tension. Moreover, in terms of role tension consequences, previous research has focused on withdrawal responses such as cynicism, reduced efficacy, and organizational commitment (Idris, O’Driscoll, \& Anderson, 
2011; Örtqvist \& Wincent, 2006). This means the present study also contributes to role tension research by showing that it can have consequences for a more proactive response: role opportunity search.

\section{Practical Implications}

This research demonstrates that our understanding of searching for new role opportunities improves if we account for the type of passion with which the individual approaches work (harmonious or obsessive) and the extent to which the person experiences role conflicts. The hypotheses were tested on managers; therefore, one must be cautious in generalizing the results to other samples. With this in mind, we still believe it is possible to derive several practical implications for how to design work to foster role opportunity search.

In redesigning work, one recommendation is to consider whether it is possible to stimulate harmonious passion and mitigate obsessive passion toward work. Literature on internalization processes (e.g., Ryan \& Deci, 2000) suggests it may be useful to try to increase the amount of self-determination in how the activity is internalized (see e.g., Liu, Chen, \& Yao, 2011). As Pelletier, Fortier, Vallerand, and Brière (2001) posited, it may be worth considering to what extent the work context is controlling (e.g., rewards, deadlines, surveillance) or supports autonomy (e.g., freedom, being involved in decision-making processes). The more supportive the environment is for autonomy, the greater the chance that the activity will be internalized autonomously. Indeed, the conceptualization of harmonious passion builds on this concept. Evidence also exists that work environments designed to maximize employees' signature strengths (what makes people excel) are positively related to harmonious passion (Forest, Mageau, Crevier-Braud, Bergeron, Dubreuil, \& Lavigne, 2012). Building on the conceptualization that obsessive passion is an inclination that originates from a controlled/pressured internalization (individuals rely heavily on the activity in question for 
own self-definition [Mageau, Vallerand, Charest, Salvy, Lacaille, Bouffard, \& Koestner, 2009]), prior research has suggested that it becomes important to carefully design the valuation system: positive feedback should be unexpected rather than expected (Ho, Wong, \& Lee, 2011). By not anticipating positive feedback, the person can more easily separate his or her own identity and self-worth from activity achievements. Besides the impact through passion, a general recommendation from these results is to try to directly reduce role conflicts. For example, an office could increase awareness of what inconsistent role expectations one has on a certain work role and identify and discuss which of these expectations should be prioritized.

\section{Limitations and Future Research}

As with all studies, the present work is not without limitations. First, we collected data from managers to test our hypothesized relationships. In such work roles, it is possible that the individual has more flexibility to shape his or her work role (Kaish \& Gilad, 1991). Before generalizations can be made to other settings, we recommend that the examined relationships be tested on other work roles, such as health care employees and teachers. Such roles may not have the same flexibility as managers. Second, our research design creates limitations in terms of investigating causality. Other research designs would be required to capture causality. Third, the body showing that obsessive passion is associated with several maladaptive consequences is growing, including the present study's emphasis on role conflict and overload. Little if any research, however, has addressed how to deal with this type of passion. The field is open, therefore, for further research to examine how organizations can deal with employees' obsessive passion once it has developed. For example, it would be interesting to examine if and to what extent therapy or coaching would be helpful. Finally, we encourage future research to expand the picture of obsessive passion in organizations by 
examining effects on both individual-level and organizational-level outcomes. Although the present study shows that obsessive passion reduces opportunity search, other parallel processes might capture the possibility that obsessive passion is instead associated with a focus on high achievement on the current task. This might be something positive even though it does not result in searching for new opportunities ${ }^{1}$. Undoubtedly, more research that elaborates on both the positive and negative sides with harmonious and obsessive passion in a work context is warranted.

\section{CONCLUSION}

The present study makes a significant contribution by demonstrating the importance of including role conflict in understanding the relationship between passion toward work and one’s search for new role opportunities. The results show that through role conflict, harmonious passion has an indirect, positive relationship to role opportunity search, whereas obsessive passion has an indirect, negative relationship to role opportunity search. With these findings, the present study informs us that we can gain a greater understanding of workers' search for new role opportunities if we apply the Dualistic Model of Passion (Vallerand et al., 2003) and take role tension into account. The present study thus indicates that management and organizations can affect workers' search for new role opportunities by aiming to create work environments that facilitate harmonious passion and mitigate obsessive passion toward work.

\footnotetext{
${ }^{1}$ We thank one of the reviewers for pointing out this avenue for future research.
} 


\section{REFERENCES}

Baum, J. R., Locke, E. A., \& Smith, K. G. (2001). A multidimensional model of venture growth. Academy of Management Journal, 44, 292-303. doi: 10.2307/3069456

Beehr, T. Walsh, J., \& Taber, T. (1976). Relationship of stress to individually and organizationally valued states: Higher order needs as a moderator. Journal of Applied Psychology, 61, 41-47.

Blau, G. J. (1988). Further exploring the meaning and measurement of career commitment. Journal of Vocational Behavior, 32, 284-297. doi: 10.1016/0001-8791(88)90020-6

Bollen, K. A. (1989). Structural equations with latent variables. New York: Wiley.

Bonneville-Roussy, A., Lavigne, G. L., \& Vallerand, R. J. (2011). When passion leads to excellence: The case of musicians. Psychology of Music, 39, 123-138. doi: $10.1177 / 0305735609352441$

Cardon, M. S., Wincent, J., Singh, J., \& Drnovsek, M. (2009). The nature and experience of entrepreneurial passion. Academy of Management Review, 34, 511-532.

Carbonneau, N., Vallerand, R. J., Fernet, C., \& Guay, F. (2008). The role of passion for teaching in intrapersonal and interpersonal outcomes. Journal of Educational Psychology, 100, 977-987. doi: 10.1037/a0012545

Caudroit, J., Boiche, J., Stephan, Y., Le Scanff, C., \& Trouilloud, D. (2011). Predictors of work/family interference and leisure-time physical activity among teachers: The role of passion towards work. European Journal of Work and Organizational Psychology, 20, 326-344. doi: 10.1080/13594320903507124 
Cooper, W. H., Graham, W. J., \& Dyke, L. S. (1993). Tournament players. In G. R. Ferris (Ed.), Research in personnel and human resources management (Vol. 11, pp. 83132). Greenwich, CT: JAI Press.

Donahue, E. G., Rip, B., \& Vallerand, R. J. (2009). When winning is everything: On passion, identity, and aggression in sport. Psychology of Sport and Exercise, 10, 526-534. doi: 10.1016/j.psychsport.2009.02.002.

Eatough, E. M., Chang, C.-H., Miloslavic, S. A., \& Johnson, R. E. (2011). Relationships of role stressors with organizational citizenship behavior: A meta-analysis. Journal of Applied Psychology, 96, 619-632. doi: 10.1037/a0021887.

Eby, L. T., Butts, M., \& Lockwood, A. (2003). Predictors of success in the era of the boundaryless career. Journal of Organizational Behavior, 24, 689-708. doi: 10.1002/job.214

Forest, J., Mageau, G. A., Sarrazin, C., \& Morin, E. M. (2011). Work is my passion: The different affective, behavioural, and cognitive consequences of harmonious and obsessive passion toward work. Canadian Journal of Administrative Sciences-Revue Canadienne Des Sciences De L Administration, 28, 17-30. doi: 10.1002/cjas.170

Forest, J., Mageau, G. A., Crevier-Braud, L., Bergeron, E., Dubreuil, P., \& Lavigne, G. L. (2012). Harmonious passion as an explanation of the relation between signature strengths' use and well-being at work: Test of an intervention program. Human Relations, 65, 1233-1252. doi: 10.1177/0018726711433134 
Fornell, C., \& Larcker, D. F. (1981). Evaluating structural equation models with unobservable variables and measurement error. Journal of Marketing Research, 18, 39-50. doi: $10.2307 / 3151312$

Fried, Y., Shirom, A., Gilboa, S., \& Cooper, C. L. (2008). The mediating effects of job satisfaction and propensity to leave on role stress-job performance relationships: Combining meta-analysis and structural equation modeling. International Journal of Stress Management, 15, 305-328. doi: 10.1037/a0013932

Gilboa, S., Shirom, A., Fried, Y., \& Cooper, C. (2008). A meta-analysis of work demand stressors and job performance: Examining main and moderating effects. Personnel Psychology, 61, 227-271. doi: 10.1111/j.1744-6570.2008.00113.x

Gustafsson, H., Hassmen, P., \& Hassmen, N. (2011). Are athletes burning out with passion? European Journal of Sport Science, 11, 387-395. doi:10.1080/17461391.2010.536573

Hmieleski, K. M., \& Corbett, A. C. (2008). The contrasting interaction effects of improvisational behavior with entrepreneurial self-efficacy on new venture performance and entrepreneur work satisfaction. Journal of Business Venturing, 23, 482-496. doi: 10.1016/j.jbusvent.2007.04.002

Ho, V. T., Wong, S. S., \& Lee, C. H. (2011). A tale of passion: Linking job passion and cognitive engagement to employee work performance. Journal of Management Studies, 48, 26-47. doi: 10.1111/j.1467-6486.2009.00878.x

Hodgins, H. S., \& Knee, C. R. (2002). The integrating self and conscious experience. In E. L. Deci \& R. M. Ryan (Eds.), Handbook of self-determination research (pp. 87-100). Rochester, NY: University of Rochester Press. 
Hodgins, H. S., Koestner, R., \& Duncan, N. (1996). On the compatibility of autonomy and relatedness. Personality and Social Psychology Bulletin, 22, 227-237. doi: $10.1177 / 0146167296223001$

Hofstede, G., Hofstede, G. J. \& Minkov, M. (2010). Cultures and organizations: Software of the mind. (3. ed.) New York: McGraw-Hill.

Ho, V. T., Wong, S. S., \& Lee, C. H. (2011). A tale of passion: Linking job passion and cognitive engagement to employee work performance. Journal of Management Studies, 48, 26-47. doi: 10.1111/j.1467-6486.2009.00878.x

Idris, M. K., O'Driscoll, M. P., \& Anderson, M. H. (2011). Longitudinal mediation effects of strain on the relationships between role stressors and employees’ withdrawal responses. Stress and Health, 27, 403-412. doi: 10.1002/smi.1392

Jaros, S. J., Jermier, J. M., Koehler, J. W., \& Sincich, T. (1993). Effects of continuance, affective, and moral commitment on the withdrawal process: An evaluation of eight structural equation models. Academy of Management Journal, 36, 951-995.

Judge, T. A., Cable, D. M., Boudreau, J. W., \& Bretz, R. D. (1995). An empirical investigation of the predictors of executive career success. Personnel Psychology, 48, 485-519. doi: 10.1111/j.1744-6570.1995.tb01767.x

Judge, T. A., Higgins, C. A., Thoresen, C. J., \& Barrick, M. R. (1999). The Big Five personality traits, general mental ability, and career success across the life span. Personnel Psychology, 52, 621-652. doi: 10.1111/j.1744-6570.1999.tb00174.x

Kahn, R., Wolfe, D., Quinn, R., Snoek J., \& Rosenthal, R. (1964). Organizational stress: studies in role conflict and ambiguity. New York: Wiley. 
Kaish, S., \& Gilad, B. (1991). Characteristics of opportunities search of entrepreneurs versus executives: Sources, interests, general alertness. Journal of Business Venturing, 6, 4561. doi: 10.1016/0883-9026(91)90005-X

Katz, D., \& Kahn, R. L. (1978). The social psychology of organizations (2nd ed.). New York: Wiley.

Knee, C. R., Neighbors, C., \& Vietor, N. A. (2001). Self-determination theory as a framework for understanding road rage. Journal of Applied Social Psychology, 31, 889-904. doi: 10.1111/j.1559-1816.2001.tb02654.x

Knee, C. R., \& Zuckerman, M. (1996). Causality orientations and the disappearance of the self-serving bias. Journal of Research in Personality, 30, 76-87. doi: 10.1006/jrpe.1996.0005

Lee, T. W., Ashford, S. J., Walsh, J. P., \& Mowday, R. T. (1992). Commitment propensity, organizational commitment, and voluntary turnover: A longitudinal study of organizational entry process. Journal of Management, 18, 15-32. doi: $10.1177 / 014920639201800102$

Liu, D., Chen, X. P., \& Yao, X. (2011). From autonomy to creativity: A multilevel investigation of the mediating role of harmonious passion. Journal of Applied Psychology, 96, 294-309. doi: 10.1037/a0021294.

Mageau, G. A., Vallerand, R. J., Charest, J., Salvy, S. J., Lacaille, N., Bouffard, T., \& Koestner, R. (2009). On the development of harmonious and obsessive passion: The role of autonomy support, activity specialization, and identification with the activity. Journal of Personality, 77, 601-646. doi: 10.1111/j.1467-6494.2009.00559.x 
Mageau, G. A., Vallerand, R. J., Rousseau, F. L., Ratelle, C. F., \& Provencher, P. J. (2005). Passion and gambling: Investigating the divergent affective and cognitive consequences of gambling. Journal of Applied Social Psychology, 35, 100-118.

Murnieks, C. Y., Mosakowski, E., \& Cardon, M. S. (in press). Pathways of passion: Identity centrality, passion, and behavior among entrepreneurs. Journal of Management. doi: $10.1177 / 0149206311433855$.

Mathieu, J. E., \& Zajac, D. M. (1990). A review and meta-analysis of the antecedents, correlates, and consequences of organizational commitment. Psychological Bulletin, 108, 171-194. doi: 10.1037/0033-2909.108.2.171

Meyer, J. P., Stanley, D. J., Herscovitch, L., \& Topolnytsky, L. (2002). Affective, continuance, and normative commitment to the organization: A meta-analysis of antecedents, correlates, and consequences. Journal of Vocational Behavior, 61, 2052. doi: 10.1006/jvbe.2001.1842

Örtqvist, D., \& Wincent, J. (2006). Prominent consequences of role stress: A meta-analytic review. International Journal of Stress Management, 13, 399-422. doi: 10.1037/10725245.13.4.399.

Pelletier, L. G, Fortier, M. S, Vallerand, R. J, \& Brière, N. M. (2001). Associations among perceived autonomy support, forms of self-regulation, and persistence: A prospective study. Motivation and Emotion, 25, 279-306. doi: 10.1023/A:1014805132406

Philippe, F. L., Vallerand, R. J., Houlfort, N., Lavigne, G. L., \& Donahue, E. G. (2010). Passion for an activity and quality of interpersonal relationships: The mediating role 
of emotions. Journal of Personality and Social Psychology, 98, 917-932. doi: 10.1037/a0018017

Przybylski, A. K., Weinstein, N., Ryan, R. M., \& Rigby, C. S. (2009). Having to versus wanting to play: Background and consequences of harmonious versus obsessive engagement in video games. Cyberpsychology \& Behavior, 12, 485-492. doi: 10.1089/cpb.2009.0083

Ratelle, C., Vallerand, R. J., Mageau, G. A., Rousseau, F. L., \& Provencher, P. J. (2004). When passion leads to problematic outcomes: A look at gambling. Journal of Gambling Studies, 20, 105-19.

Rizzo, J. R., House, R. J., \& Lirtzman, S. I. (1970). Role conflict and ambiguity in complex organizations. Administrative Science Quarterly, 15, 150-163.

Ryan, R. M., \& Deci, E. L. (2000). Self-determination theory and the facilitation of intrinsic motivation, social development, and well-being. American Psychologist, 55, 68-78. doi: http://dx.doi.org/10.1037/0003-066X.55.1.68

Short, J. C., Ketchen, D. J., Shook, C. L., \& Ireland, R. D. (2010). The concept of “opportunity” in entrepreneurship research: Past accomplishments and future challenges. Journal of Management, 36, 40-65. doi: 10.1177/0149206309342746

Sobel, M. E. (1982). Asymptotic confidence intervals for indirect effects in structural equations models. In: Leinhart, S. (Ed.), Sociological methodology. Jossey-Bass, San Francisco, pp. 290-312. 
Stenseng, F. (2008). The two faces of leisure activity engagement: Harmonious and obsessive passion in relation to intrapersonal conflict and life domain outcomes. Leisure Sciences, 30, 465-481. doi: 10.1080/01490400802353224.

Stenseng, F., Rise, J., \& Kraft, P. (2011). The dark side of leisure: Obsessive passion and its covariates and outcomes. Leisure Studies, 30, 49-62. doi: 10.1080/02614361003716982.

Stoeber, J., Harvey, M., Ward, J. A., \& Childs, J. H. (2011). Passion, craving, and affect in online gaming: Predicting how gamers feel when playing and when prevented from playing. Personality and Individual Differences, 51, 991-995. doi: 10.1016/j.paid.2011.08.006.

Tillväxtverket [Swedish Agency for Economic and Regional Growth] (2011). Företagens villkor och verklighet 2011 [The situation and conditions of enterprises 2011]. Stockholm: Tillväxtverket.

Tubré, T. C., \& Collins, J. M. (2000). Jackson and Schuler (1985) revisited: A meta-analysis of the relationships between role ambiguity, role conflict, and job performance. Journal of Management, 26, 155-169. doi: 10.1177/014920630002600104.

Turban, D. B., \& Dougherty, T. W. (1994). Role of protégé personality inreceipt of mentoring and career success. Academy of Management Journal, 37, 688-702.

Vallerand, R. J., Blanchard, C., Mageau, G. A., Koestner, R., Ratelle, C., Leonard, M., Gagne, M., \& Marsolais, J. (2003). Les passions de l'Ame: On obsessive and harmonious passion. Journal of Personality and Social Psychology, 85, 756-767. doi: 10.1037/0022-3514-85.4.756. 
Wang, C. C., \& Chu, Y. S. (2007). Harmonious passion and obsessive passion in playing online games. Social Behavior and Personality, 35, 997-1005.

Verner-Filion, J., Lafreniere, M. A. K., \& Vallerand, R. J. (2012). On the accuracy of affective forecasting: The moderating role of passion. Personality and Individual Differences, 52, 849-854. doi: 10.1016/j.paid.2012.01.014

Wincent, J., \& Örtqvist, D. (2009). A comprehensive model of entrepreneur role stress antecedents and consequences. Journal of Business and Psychology, 24, 225-243. doi: 10.1007/s10869-009-9102-8. 
Table 1. Model Comparison

\begin{tabular}{|c|c|c|c|c|}
\hline Hypotheses & Relationships & Saturated model & Direct effects model & Hypothesized model \\
\hline H1a & Harmonious passion $\rightarrow$ Role conflict & $-.14^{* *}$ & $-.14^{* *}$ & $-.14^{* *}$ \\
\hline $\mathrm{H} 1 \mathrm{~b}$ & Obsessive passion $\rightarrow$ Role conflict & $.44^{* * *}$ & $.44^{* * *}$ & $.44^{* * *}$ \\
\hline $\mathrm{H} 1 \mathrm{c}$ & Role conflict $\rightarrow$ Opportunity search & $-.19 *$ & & $-.21 *$ \\
\hline $\mathrm{H} 2 \mathrm{a}$ & Harmonious passion $\rightarrow$ Role overload & $-.26 * * *$ & $-.26 * * *$ & $-.26 * * *$ \\
\hline $\mathrm{H} 2 \mathrm{~b}$ & Obsessive passion $\rightarrow$ Role overload & $.41 * * *$ & $.41^{* * *}$ & $.41^{* * *}$ \\
\hline $\mathrm{H} 2 \mathrm{c}$ & Role overload $\rightarrow$ Opportunity search & .04 & & .04 \\
\hline & Harmonious passion $\rightarrow$ Opportunity search & -.03 & .01 & \\
\hline & Obsessive passion $\rightarrow$ Opportunity search & -.03 & -.12 & \\
\hline \multicolumn{5}{|c|}{ Model fit indices } \\
\hline & $\chi^{2}(d f)$ & $531.84(122)$ & $538.79(124)$ & $532.44(124)$ \\
\hline & RMSEA & .07 & .07 & .07 \\
\hline & GFI & .92 & .92 & .92 \\
\hline & IFI & .90 & .90 & .90 \\
\hline
\end{tabular}

$n=704$

${ }^{*} p<.05 ;{ }^{* *} p<.01 ; * * * p<.001$ 
Figure 1. Results for the Hypothesized Model ${ }^{\mathrm{a}}$

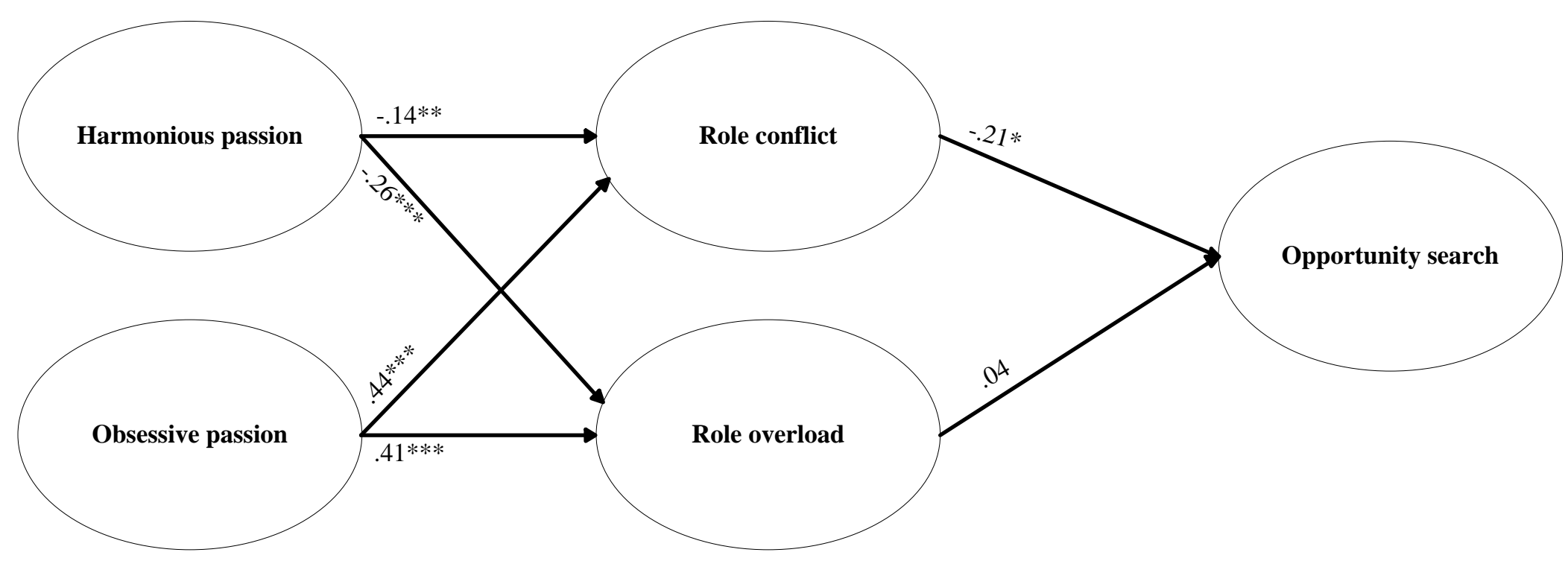

${ }^{\mathrm{a}}$ Fit: $\chi^{2}[124, n=704]=532.44$; RMSEA $=.07$; GFI $=.92$; IFI $=.90$. Coefficient estimates are from the standardized solution . $* * p<.01$; *** $p<.001$ 